\title{
Exports, \\ Outward-oriented Development, and Economic Growth
}

OOD.205

30 September 1997

Bruce E. Moon

Dept. of International Relations

Lehigh University

Bethlehem, PA 18015

\begin{abstract}
TheWorldBank has urged poor nations to adopt developmentstrategies whichemphasize export expansion, dismissing the caution againstexcessive trade dependence voiced by politicaleconomists. In reexamining the Bank's much-citedanalyseswhich suggestthat"outward-oriented"nations haveexperienced more rapid growth, thisstudy uncovers three findings which challenge its apparentimplications. First, nations characterizedas following outward-oriented development do nottrade notably more than those regarded as inward-oriented. Second, outward-oriented nations do not expand their trade at a rate strikingly differentfrom other countries. Third, itis notapparent that export expansion is the principal source of the superior macroeconomic performance of so-called "outward-oriented" nations. These findings raisequestions aboutwhat is meantby "outward-oriented development". Moreover, because the structural claims of political economists concerning the dangers of trade dependence cannotbeeasily refuted, the counsel that nations should focus development efforts on expanding exports needs to be very carefully circumscribed.
\end{abstract}


Theorists have long debated the relative merits of development strategies which accord priority to expansion of the foreign sector in contrast to those which emphasize inward-oriented development (Bhagwati, 1986; Reidel, 1988). Among economists, the balance has swung in favor of acknowledging the superior growth performance of nations that have opted for outward-oriented development (OOD), particularly in recent years with the discrediting of import-substituting industrialization (ISI), the most visible branch of more inward-oriented strategies (Bhagwati, 1978; Krueger, 1978).

However, political economists have been more reluctant to endorse a strategy supported by such limited historical precedent. Senghaas (1985) observes that European development success was largely internally generated while Frank (1966) notes that such advice is also at variance with the experience of Latin America, which grew most rapidly during periods of de-linking from the global economy. Both caution against the potential dangers of trade dependence. Meanwhile, policy makers have juggled competing theoretical ideas while accommodating both domestic political forces, which on balance drive policy in an inward direction, and international forces, which generally incline policy toward a more outward orientation.

The World Bank, which has advocated OOD strategies for some time, has published much-cited analyses that demonstrate that "outward-oriented" nations have experienced especially rapid growth (World Bank, 1987: chapter 5). The mission of this article is to re-evaluate the evidence supporting OOD and the policy advice which seems to flow from it. To accomplish that mission, this study probes the causal mechanisms which underlie the superior growth performance of nations pursuing OOD. It also confronts the case for outward-oriented development with the case against trade dependence.

This article contains three findings which challenge the apparent implications of the World Bank studies. First, nations characterized as following outward-oriented development do not manifest levels of trade notably higher than those regarded as inward-oriented. Second, outward-oriented nations expand their trade, but not at a rate strikingly different from other countries. Third, it is not apparent that export 
expansion is the principal source of the superior macro-economic performance of outward-oriented nations. Taken together, these findings raise questions about what is meant by "outward-oriented development".

Accordingly, the counsel that nations should focus development efforts on expanding exports needs to be very carefully circumscribed, especially because the structural claims of political economists concerning the dangers of trade dependence cannot be easily refuted. Thus, the World Bank study does not settle the question of the relative merits of outward and inward oriented development, though it does steer the discussion in a very helpful direction.

\section{Exports, imports and growth}

The role of the foreign sector in fostering macro-economic growth has long been controversial. According to the orthodox economic view, imports should be welcomed because exposure to the competitive pressures of international trade stimulates growth by encouraging the efficient allocation of resources and by introducing innovation and learning from abroad (Corden, 1971; Bhagwati and

Srinivasan, 1979; Pack, 1988). Exports expand aggregate demand, encourage full employment of resources, and earn revenues to pay for the imports which enhance consumption and facilitate technological progress. The orthodox position is exemplified by Nurkse's (1961) characterization of trade as the "engine for growth" that drove the global economy of the nineteenth century.

More structural theorists have questioned the wisdom of relying heavily on external markets, particularly for contemporary Third World economies (Myrdal, 1957). Because their traditional exports frequently lie in sectors that offer unattractive demand prospects and limited inter-sectoral linkages (such as primary products and very low wage assembly), significant expansion of existing industries may be neither possible nor desirable (Prebisch, 1962; Cline, 1982). Meanwhile, a flood of imports from more established foreign firms may prevent the development of new domestic industries. Thus, trade dependence may lead to distortions which compromise future growth opportunities (Galtung, 1971; Frank, 1966; Emmanuel, 1972). Moreover, heavy reliance upon trade may leave a nation dangerously vulnerable to market disruption or political pressures, particularly if that trade is concentrated in a small number of 
products and a small number of trade partners (as is typical for small and poor economies). At the extreme, national autonomy may be compromised.

In between these two positions is Kravis (1970), whose challenge to Nurkse's interpretation depicts trade as only a "handmaiden of growth". Kravis contends that trade was as much a consequence as a cause of growth, that trade was only one cause among many for economic growth, that it worked only for some nations under some conditions, and, most importantly, that "the mainsprings for growth were internal" (p. 859). In support of Kravis's pessimism about the role for exports, Lewis (1978) adds another analogy, "the engine of growth should be technological change, with international trade serving as a lubricating oil and not as fuel."

Many advocates of outward-oriented development, confident of the pure economic theory which underlies OOD, derisively dismiss the reservations of social scientists. Buoyed by the evident limitations of Latin American ISI in the 1970's, they question whether import restrictions can ever be reconciled with export expansion and whether growth can occur without an emphasis on the foreign sector. Still, the empirical evidence remains inconclusive. Overall, trade levels are not consistently linked to economic growth (Rubinson, 1977; Delacroix, 1977; Mahler, 1980) and the best evidence suggests that, contrary to theory, trade does not enhance resource allocation, though it is associated with higher investment levels (Levine and Renelt, 1992). Even the interpretation of the statistical relationship between export growth and GDP improvement is contested, owing to the difficulty in definitively separating the presumed two-way causation (Crafts, 1973; Smith, 1975; Michaely, 1977; Ram, 1985; Jung and Marshall, 1985; Hsiao, 1987).

The empirical evidence concerning the performance of contemporary nations pursuing alternative strategies is even more ambiguous, principally because it has not been possible to devise a reliable measure of adherence to "outward-oriented development" or "export-oriented policies" (EOP), as it is sometimes known (Harrison, 1991; Leamer, 1988; Milner, 1988). In place of a direct measure of policy orientation, many prior analyses have relied upon the actual volume of trade to infer the presence of policies designed either to expand trade or to restrict it (Choi, 1983). This approach, of course, makes the dubious assumption that state policy is entirely responsible for the differences in propensities of nations to engage 
in trade. In fact, trade policy accounts for only modest differences in export levels, which are dominated by cross-national variance in economic size and resource endowments and cross-time variation in effective external demand as well as supply conditions.

\section{The World Bank study}

Without a direct measure of policy, it has been difficult to assess systematically the performance of alternative development strategies. The World Bank sought to overcome this obstacle by employing a new measure of "trade orientation" constructed independently of trade volumes. The coding scheme was first introduced in the Bank's World Development Report 1987 but was originally constructed in a background paper by Greenaway (1986). He codes 41 nations into one of four categories for the time periods 1963-73 and 1973-85 based upon the criteria of effective rate of protection, the use of direct trade controls and export incentives, and the degree of exchange rate overvaluation (Greenaway and Nam, 1988):

\section{Strongly outward-oriented \\ 3 Moderately outward-oriented \\ 2 Moderately inward-oriented \\ 1 Strongly inward-oriented}

The macroeconomic performance of the groups of nations fitting each category of trade orientation was then used to evaluate the merits of each approach. In both the World Bank study and in this one, the developmental orientation and growth rate of each nation is recorded separately for each period. This is necessitated not only by policy shifts -- nearly $40 \%$ (15 of 41) of the nations are coded differently in the two periods - but by shifting prospects and determinants of growth in these different eras. Annual per capita real growth rates averaged about $2.7 \%$ between 1963 and 1973 but under $1 \%$ - with greater variance - between 1973 and 1985. Further, only about $25 \%$ of the variance in a nation's growth rate in one period is common to the other.

Despite the serious reservations expressed below about the interpretation of these results, it must be made clear that the fundamental claim of the World Bank analyses is indisputable: the less inwardly oriented economies grew at a faster rate than the more inwardly oriented. Furthermore, it appears that 
the performance improved steadily as one moved from strongly inward-oriented to strongly outwardoriented. Table 1 reprints the findings of Greenaway and Nam (1988) in the first two columns, with the replication by this study reported in the last two columns. The results are very comparable, despite differences in the methods used to compute growth rates. ${ }^{1}$

\section{[Table 1 here]}

Furthermore, this generalization is well sustained by the empirical evidence cited by other studies and also replicated here. Regression analyses indicate that this measure of trade orientation (scaled 1 to 4) is positively associated with subsequent gains in real GDP per capita. The respective t ratios for the two periods -- 7.5 and 5.6 -- are significant well beyond conventional thresholds and the $\mathrm{R}^{2}$ values of .59 and .44 are impressive for a two variable regression model. ${ }^{2}$ When the single trade orientation variable is expanded into a series of three dummy variables corresponding to the membership of each category (with the strongly inward omitted), the pattern of more rapid growth among the most outward nations displayed in Table 1 is revealed to be statistically significant.

Moreover, these results also hold up in the context of a more complete model which includes known correlates of growth frequently found in the published literature (Heitger, 1986; Barro, 1991; Moon and Dixon, 1992). Table 2 reports the results of analyses which use a control model consisting of three independent variables: investment as a percentage of real GDP at the beginning of each period (Summers and Heston, 1988), a measure of initial basic needs attainment which serves as a proxy for human capital, ${ }^{3}$ and logged real GDP to reflect the propensity of poorer nations to grow somewhat more rapidly. Missing data on the investment variable reduces the sample to 40 . In column 1, the single trade orientation variable is used, while in column 2 it is replaced by the series of trade orientation dummies. From the former, we note that the inclusion of this control model improves the fit yet reduces only very slightly the apparent effect of trade orientation on growth reported above. From the latter, we can see that growth improves steadily as one moves from strongly inward-oriented to strongly outward-oriented. Thus, the effect is not produced merely by the very weak performance of the most inwardly oriented nations and the very strong performance of Korea, Hong Kong, and Singapore -- the nations which constitute the strongly outward oriented category in both time periods. Furthermore, nearly all of these coefficients are significantly 
different from those of the other categories. In these and all subsequent tables, the "strongly inward oriented" category is the base-line from which the deviations of other categories are computed. Thus, the number in parentheses is the $t$ value associated with the difference of means between each category and the strongly inward oriented grouping.

\section{[Table 2 here]}

Taken by themselves, these analyses would appear to constitute impressive evidence in support of the World Bank's long-held view that outward-oriented development offers substantially better growth prospects than inward-oriented development. This study became an influential and heavily cited statement of the relative merits of alternative policies not only because its support of a popular theoretical position appeared in a prominent Bank publication, but also because its strong empirical findings were produced with an innovative measure that avoided the acknowledged drawbacks of previous work. However, as we shall see, by divorcing "trade orientation" from actual trade volumes, the Bank's measure substitutes one conceptual weakness for another and thus may yield misleading results. Moreover, because these findings could be produced by several different causal dynamics, this approach may encourage a misunderstanding of the role of exports in these economies as well as the processes that produce growth in them.

Initial skepticism is prompted by a seeming contradiction in development theory: while an outward orientation appears to speed subsequent growth, many have suggested that heavy reliance on the foreign sector may limit growth potential.

\section{Trade dependence and macro-economic growth}

Political economists have issued warnings about three inter-related dimensions of trade, each of which is sketched below. First, a large foreign trade sector may itself constrain future growth. Second, growth prospects may be damaged not by trade itself but by the excessive specialization in a single export commodity which sometimes accompanies it. Third, the particular product chosen as the specialization may be critical, with primary product exports usually singled out for criticism.

The principal objection to a large foreign trade sector centers on its tendency to strengthen dependence on external economies but to limit internal integration of the various parts of the domestic 
economy (Hirschman, 1958). There are several implications. In particular, development success becomes contingent upon events outside the control of the nation, especially the policies of other governments. Unable to control the environment, the state is unable to plan coherently. The absence of domestic linkages constrains future growth by diminishing the stake of many economic actors in the domestic economy while encouraging them to look abroad for growth opportunities. Thus, many of the positive externalities, spin-off effects, and backward and forward linkages associated with development cannot be captured by the domestic economy and instead redound to the benefit of other nations.

Trade requires all nations to engage in greater specialization than would otherwise be the case, but for small economies and those with a very narrow range of comparative advantage, that specialization can become excessive dependence (Nurkse, 1961). At an extreme, specialization engenders uneven development that cannot be self-sustaining. In particular, relatively small fluctuations in supply or demand conditions within a single export industry can doom an entire nation's economy to severe instability while long-term changes in a single product can condemn an economy to stagnation or decline.

This is particularly dangerous when the specialty export is itself prone to volatility and/or long-term decline in price and/or volume. Many have suggested that these characteristics perfectly describe the primary products which make up a dominant share in the exports of many Third World countries (Singer, 1950; MacBean, 1966; Robinson, 1979). See Delacroix (1977) for a review of the literature describing the limitations of primary product exports as a center-piece of development, which center on the relatively weak growth dynamic induced by isolated export enclaves as well as questions of price and demand volume. Reliance on the export of the South's other comparative advantage -- low-wage, unskilled laborintensive manufactures -- is also viewed with skepticism by many structural analysts, but the more complex arguments involving wage stagnation, excessive supply, inequality, and foreign financing are more difficult to operationalize and, in any case, well beyond the bounds of this article.

Together, these arguments appear to challenge both the theory and the evidence concerning the effects of outward-oriented development on growth. In the analysis below we seek to determine if trade reliance accelerates or inhibits macro-economic growth. The first claim by critics of trade dependence - 
that a large foreign sector is itself damaging - is addressed in Table 3 while the others are evaluated in the analyses reported in Table 4.

We begin with an analysis parallel to that reported in Table 2 except that the World Bank measure of trade orientation is replaced by a measure of the size of the foreign sector at the beginning of the period, exports as a percentage of GDP. ${ }^{4}$ Because the foreign sector share is known to be systematically related to the size of the economy (as size increases, trade as a percentage of GDP declines), "openness" is sometimes estimated as the residual from a regression analysis in which that share is the dependent variable and various measures of size are the predictors (Heitger, 1986; Leamer, 1988; Syrquin and Chenery, 1989). Both of these measures have been previously used in the literature to estimate a nation's trade orientation; thus, the results provide an interesting comparison to the findings using the World Bank's more direct policy measure. The analysis reported in Table 3 was conducted using the raw form of exports as a percentage of GDP, but substituting the measure derived from the auxiliary regressions does not in any way alter the analysis. ${ }^{5}$ For reasons elaborated in the technical appendix, the coefficients in Table 3 were computed using a bounded influence estimator (BIE) in place of ordinary least squares (OLS).

\section{[Table 3 here]}

The insignificant $t$ values in the first column indicate that by itself the openness of the economy does not greatly affect growth prospects: more open economies are neither more nor less likely to experience subsequent macro-economic growth. ${ }^{6}$ The second column of Table 3, which replicates the second column of Table 2 (allowing a comparison of the BIE estimator used in the former with the OLS estimate of the latter), confirms that more outward-oriented nations produce more rapid growth. While there is nothing inherently contradictory in these two results, it is at least curious that "outward orientation" and "openness" -- seemingly similar concepts -- produce such different outcomes.

The third column reports the initial attempt to sort out the relative contribution of these two dimensions of trade by including both as predictors of growth. The striking findings are two-fold. First, controlling for trade orientation, nations engaged in greater trade do somewhat less well, though the effect is small and, in the earlier period, statistically insignificant. Second, including the measure of openness has only a small effect on the parameter estimates for the trade orientation dummies. This strongly confirms 
that "trade orientation" exerts a powerful positive influence on growth, but also suggests that it may operate independently of the size of the foreign sector.We return to this critical point below after assessing the remaining concerns about trade dependence.

In the first column of Table 4, the now familiar model of GDP growth rates is augmented with a measure of the degree to which exports are centered on a single product. The estimation reported in the second column includes the percentage of exports composed of non-fuel primary products while the third column contains the growth in that percentage during each period. ${ }^{7}$ It is apparent that each of these indicators of trade dependence is associated with a strong negative impact on growth for both periods, thus seeming to sustain the position of political economists skeptical of trade specializations common to exportoriented Third World nations. Such a conclusion must be tempered, however, by the results reported in columns 4 through 6 . When the dummy variables representing "trade orientation" are included in the analysis, the parameter estimates for the dependence measures remain negative, but only three of the six are statistically significant.

\section{[Table 4 here]}

Still, this analysis leaves us with a puzzle. If an open economy doesn't grow any more rapidly than a relatively closed one, how does outward-oriented development -which is designed to produce an open economy -- augment growth? The key to resolving the apparent contradiction between the negative effect of trade dependence and the positive effect of outward-oriented development may lie in the surprising suggestion from Table 3 that the effect of "trade orientation" on growth operates independently of the size of the foreign sector. This possibility requires further probing because it goes to the heart of the motivation for outward-oriented development. More generally, before we can confidently offer strategic advice, we must be able to sketch a persuasive representation of the causal mechanism whereby "trade orientation" leads to accelerated GDP growth. The presumed stimulative effect of outward orientation on export growth must surely be the most plausible candidate for such a mechanism.

Accordingly, a regression that includes both trade orientation and export growth may tell us something about how trade orientation leads to macro-economic growth and thus help to reveal the real 
significance of the bundle of policies here labeled "trade orientation". Specifically, if the principal mechanism is export expansion, then including a measure of export growth should sharply reduce the coefficients of the trade orientation variables (Simon, 1957).

Table 5, which includes such a measure, does offer an interesting insight. ${ }^{8}$ From the first column we see the expected effect: export growth is associated with GDP growth. The second column repeats the now familiar finding of the World Bank. It is column 3, however, that produces the result of real interest. When export growth and trade orientation variables are included in the same equation, the parameter estimates for both the dummy variables and exports remain sizable. With the exception of export growth in the early period, they all retain their statistical significance. Indeed, with the exception of the moderately outward category in the later period, none of the parameter estimates of the dummies are reduced more than about $10 \%$ by the inclusion of export growth in the estimating equation. Nor is the statistical significance of those estimates much changed. In short, there is no sign of the characteristic patterns which ordinarily indicate a structure of indirect causation through an intervening variable (Hilton, 1976). In analyses not shown, the design of Tables 3 and 5 was repeated with exports as a percentage of GDP replaced by imports as a percentage of GDP and by the shares of exports comprised of manufactured goods and non-fuel primary products. No indication was found of any trade related indicator serving as an intervening variable between trade orientation and economic growth. That is, these results imply that the principal mechanism by which trade orientation affects GDP growth does not involve expansion of the foreign sector.

\section{[Table 5 here]}

If that is true, it creates one mystery even while solving another. The finding suggests that the argument in favor of OOD may be perfectly compatible with the argument against trade dependence simply because one need not imply the other. But, if export expansion is not the mechanism by which OOD leads to economic growth, what is the identity of this mysterious mechanism?

One possibility is that rising exports boost macro-economic growth in outward-oriented nations, but not in others. Such an argument has great intuitive appeal because it would reconcile the pro-trade arguments of OOD advocates with the anti-trade arguments of those concerned with dependence. To test 
this suggestion, the model represented in the third column of Table 5 was augmented by replacing the single term "export growth" with four interaction terms (export growth multiplied by each of the four dummies). Surprisingly, it appears that export expansion is more likely to lead to macro-economic growth in the inward-oriented than the outward-oriented nations. In both periods, the only significant interaction terms represented the positive effect of trade growth among the strongly inward group. Three of the four coefficients involving the outward groups were negative, though the $t$ values, ranging between -1.8 and -2.0 , fell just short of significance at the .05 level. This counter-intuitive outcome is intriguing -- and confirmed by the pooled cross-sectional analysis of Salvatore and Hatcher (1992) -- but beyond the bounds of this paper to examine in greater detail.

It does, however, suggest still another plausible theoretical explanation that can be addressed within this research design: that changes on the import side are distinctive among outward-oriented nations. Import expansion in the aggregate is not usually accorded a prominent role as a source of growth, even though the liberalization of import controls and the reduction in the anti-import bias of the price structure (especially in foreign exchange) is central to the strategy of OOD. Instead, its advocates anticipate that the import expansion which results from OOD will have a different commodity make-up and a very different macro-economic effect than imports under an inward-looking trade regime. Specifically, increased imports should be concentrated in sectors which displace inefficient domestic production, forcing either improved efficiency within an existing industry and/or an inter-industry shift of investment to a more efficient sector. If import growth has such a different character across different economic policy environments, it should produce a distinctive pattern of effects among interaction terms. That is, import growth should produce more positive effects among outward-oriented economies than elsewhere. Alas, an analysis of interaction terms parallel to that described above discounts this possibility. In the 1963-73 period, import growth was significantly associated with macro-economic growth only among strongly inward nations (where it was positive); all other categories showed a negative relationship, with t's ranging from -1.4 to -2.0. In the later period, both inward-oriented categories showed sizable but insignificant positive coefficients $(\mathrm{t}=1.8$ and 1.5 , respectively), while the outward categories revealed little relationship at all ( $\mathrm{t}=.9$ and -1.1$)$. 
No doubt, alternative research designs might probe deeper into the mystery concerning the mechanism linking trade orientation and growth. For example, time-series analysis in the vein of Feder (1972) might better probe spin-off effects or more elaborate comparative modeling might uncover different macro- or even micro-economic dynamics in different types of economies. However, the failure of the most obvious explanations involving the trade sector itself must also lead us to question the construction of the trade orientation index -- and what it means for a nation to pursue "outward-oriented development". The seeming contradiction between the effects of an outward trade orientation and the consequences of trade dependence already suggest that there is much more to the trade orientation index than trade.

\section{Trade intensity and trade orientation}

Table 6 makes it quite clear that the strategy identified by the World Bank coding scheme as "outward-oriented development" (OOD) or "export-oriented policies" (EOP) is very different from the concept of "trade level" or "openness" of the economy. Indeed, there is a surprisingly small relationship between trade orientation in policy terms and actual trade levels, particularly at the beginning of each period, when only the "strongly outward" category (Hong Kong, Korea, and Singapore) is distinct. ${ }^{9}$ The first two columns document that these three nations engaged in much more trade than any of the others at the beginning of both periods, but no contrast among the other groups is significant. Indeed, when the raw value of trade as a percentage of GDP is replaced with the relativized measure which adjusts for the greater trade necessary for a small economy, even this group is seldom significantly distinct from any but the strongly inward group.

\section{[Table 6 here]}

Nor does a consistent pattern emerge from an examination of the change in trade levels during these two periods, presented in columns three and four. ${ }^{10}$ The strongly outward nations increase the export ratio -- but not the import ratio -- more rapidly than any of the others, but only in the early period (and only the contrast with the strongly inward group is statistically significant). This is not too surprising since their trade levels were already extremely high, but the lack of pattern among the other groups is less easily explained. The moderately inward group's trade growth was significantly greater than that of the strongly inward only 
with respect to imports in the early period -- and was actually smaller (though not significantly) in that same category in the later period. The moderately outward had significantly greater trade growth than the moderately inward in only one of four comparisons and a little less in one. In short, only 5 of 24 contrasts in trade growth rates were statistically significant.

As illustrated in columns 5 and 6, even by the end of the periods, the differences among the three least outward categories were small. None of the eight contrasts between adjacent categories was significant and two of these were in the "wrong" direction, since both the import and export ratio of the moderately inward group was actually greater than that of the moderately outward by the end of the early period. The variance within each category was large enough to render insignificant the differences between categories.

Before concluding that the three most inward categories do not display any significant differences in trade patterns, however, we take note of the accounts which emphasize that the benefits of outwardoriented development derive not only from higher trade levels but also from an improved product composition of exports (Thomas et. al., 1971). That is, they contend that the share of manufactured exports rises and the share of primary product exports falls in outward oriented economies. If empirically confirmed, this feature of OOD would go a long way toward alleviating the reservations of those who fear that emphasizing exports unwisely requires specialization in sectors of the economy that offer poor prospects for long-term growth and development.

Table 7 shows, however, that "trade orientation" tells us very little about either the product composition of exports at the beginning of the period or changes in that composition during the time these policies are in place. Column 1 presents the percentage of exports composed of manufactured goods initially while column two registers the subsequent change in that percentage. Columns three and four duplicate the analysis with non-fuel primary products. Only the three nations in the most outward-oriented category are significantly different from the others. When change in the composition is examined, there is virtually no relationship at all. In sum, it is evident that the trade orientation schema is measuring something very different from the propensity of nations to export or even to increase their reliance on foreign trade or change its product composition. 


\section{[Table 7 here]}

In fact, the inability of measures based on relative prices (as the World Bank schema is) to predict actual trade levels is apparently a common property not unique to this scale. Harrison (1991) examines the cross-sectional relationship between several other static measures of "openness", including trade levels. Only 1 of 5 measures was significantly related to trade levels at even the .15 level. Furthermore, only five of the fifteen correlations among these measures were significant at .15 and only 3 of those at 05 . When she examined changes in openness, she found that only four of 21 cross-sectional correlations among alternative measures were significant at .05 . Other researchers report similar divergences between alternative measures. Dollar (1992: 532) constructs the most ambitious price-based measure of outward orientation and concludes that "[his] division of countries is highly consistent with the [Greenaway and Nam, 1988] categorization and with other studies." However, he cites a rank correlation with Greenaway and Nam of only .51 and with Leamer (1988) of only .41-- even after removing 2 cases with opposite codings. Harrison notes (1991: 13) "The lack of a perfect (or even appropriately signed) correlation between all these measures is likely to indicate that they are not capturing the same aspects of 'openness'." I would go further: there is little evidence that they are even measuring the same concept. They are surely not measuring the dimensions of trade dependence emphasized by structural theorists.

Moreover, outward-oriented nations do not appear to be distinguished by other measures of contact with the international economic system either. In analyses not shown, receipts of foreign aid, debt levels, and capital flows are broken down by trade orientation. With respect to foreign aid as a percentage of GDP, for example, it is the inward-oriented with the greatest external reliance and the outward-oriented with the smallest, though when GDP is introduced as a predictor any relationship between aid and trade orientation disappears entirely. Neither does an examination of debt levels reveal any systematic relationship with trade orientation. ${ }^{11}$ Finally, neither trade deficits nor net long-term capital flows manifested any interpretable patterns, while the net foreign direct investment analysis revealed that the strongly outward category received significantly more FDI than the strongly inward category, but no other contrast was significant. 
In short, outward-oriented nations may be marked by policies that produce a characteristic impact on relative price levels, but they do not appear to be distinguished by any other attribute that would coincide with a common sense understanding of what it means to be "outward-oriented". This certainly explains why our earlier analyses suggested that the beneficial effects of trade orientation are not primarily centered on trade growth. It also explains how trade dependence and "trade orientation" can have such different impacts on growth.

But, if an outward policy orientation is not associated with an especially large foreign trade sector initially, does not make the economy significantly more dependent upon trade, does not cause manufactured exports to grow or primary product exports to fall, is not associated with greater foreign aid receipts, debt balances, or capital flows, then what exactly constitutes an "outward orientation"?

\section{Measuring development strategy}

One clue is to be found in a striking resemblance between this measure of "trade orientation" and an earlier World Bank (1983: chapter 6) measure of "distortions" involving the pricing of goods as well as capital, labor, and foreign exchange. That "composite distortion index" is compiled for 31 nations (including 28 of those contained in this sample) for "the 1970's". The correlation between the distortion index and the trade orientation index is .60 and .55 for the 1963-73 and 1973-85 periods, respectively. By contrast, the correlation between trade orientation and actual export level is .13 and .24 at the beginning of the two periods and .49 and .60 at the end of them. Thus, "trade orientation" appears to have as much in common with "distorted prices" -- that is, illiberal intervention and/or policy ineptness -- as it does with a propensity to trade. It is ill-named. And it threatens to provide poor advice as a result. It surely cannot constitute a refutation of the concerns of structural theorists who caution against over-reliance on trade.

A closer examination of this coding scheme reveals several reasons why caution is warranted in interpreting the results of analyses that use it. First, the labels applied to these four categories are potentially 
quite misleading. Greenaway and Nam (1988:421) make it clear that "the distinction between an inward oriented and outward oriented strategy is straightforward, turning upon the manner in which relative prices are influenced by the instruments of commercial and industrial policy." But, in this sense, none of these nations are truly biased in favor of exports and only the nations occupying category 4 have an incentive structure which is essentially neutral with respect to production for export vs. import substitution. Greenaway and Nam (1988:423) acknowledge that all the other nations, including those coded as moderately outward-oriented, have incentive structures -- particularly import barriers and over-valued exchange rates -- which are "biased toward production for domestic rather than export markets" in varying degrees. Thus, the conclusion trumpeted by the World Bank (1987:85) - "the figures suggest that the economic performance of the outward-oriented economies has been broadly superior to that of the inwardoriented economies" must be re-interpreted to counsel that the optimal policy appears to consist not of biasing production decisions toward exports, but only biasing them less toward imports.

Second, this schema presents a one-dimensional image of development policies arrayed along a continuum of trade orientation, a vision that stands in stark contrast to the multitude of development strategies recognized by the broader literature (Griffin, 1989; Syrquin and Chenery, 1989). In fact, while "trade orientation" is presented as uni-dimensional, it appears to combine at least three dimensions of policy that ought properly to be distinguished. One, which might be termed "liberalization" (Pritchett, 1991; Dean et. al. 1994), concerns the extent to which market forces are allowed to operate without policy intervention. Another, "neutrality", evaluates the degree of bias between exporting and import-competing sectors that is introduced by the interactions among various policy interventions, whatever their absolute levels. The third addresses the coherence of the policy package and the skill with which it is applied; this "competence" element describes whether the various interventions achieve any systematic vision of intended biases. Conflating these three dimensions has analytic costs: it compromises our ability to isolate the effects of an outward orientation from those of liberalization and coherent policy implementation while it may unfairly prejudice the choice between outward- and inward-oriented development. To see this confusion most clearly, we must examine the nations which make up both the strongly outward- and strongly inwardoriented categories. 
Only three nations - Hong Kong, Korea, and Singapore - constitute the outward-oriented group for each time period (see Appendix B). The distinctive export profile and outstanding growth performance of these "tigers" is well-known, but for a number of reasons a sample of three is a dangerously small basis upon which to draw inferences. For example, it has been suggested that vigorous promotion of laborintensive products for sale in a relatively few markets may be successful only for a very small number of nations at any one time (Cline, 1982). Moreover, these heterogeneous nations may possess singular but unmeasured features that confuse causal inference. For example, Hong Kong and Singapore have both unique trade requirements and uncommon political alignments because they lack a rural sector. More importantly for our purposes, these three do not share the degree of liberality that plays such an important role in the arguments cited in support of OOD theory and in the policy advice seemingly implied by research which validates the success of OOD strategies. As Greenaway and Nam (1988: 433) acknowledge, both Korea and Singapore have promoted export expansion through vigorous intervention. In fact, the commonality among these three strategies may lie less in either "liberality" or "neutrality" than in "competence". Thus, diminishing anti-export bias may be as much a side effect of getting prices consistent as it is a defining characteristic of OOD.

In this regard, one must also note with interest the list of nations occupying the strongly inward category over both time periods: Dominican Republic, Ghana, India, Tanzania, Sudan, Ethiopia, Peru, Bangladesh, Burundi, Zambia, and Argentina. By any standard, this is a mixed group. Some -- perhaps India would be the best example -- might be thought of as nations that have deliberately selected and competently implemented an industrialization strategy that focuses on inward development and relegates exports to a decidedly peripheral role. Others, such as Tanzania, have also maintained a distinctive, though hardly conventional, development orientation that stresses redistribution while de-emphasizing external connections. Bangladesh has emphasized rural development, in part through the green revolution. Argentina's import-substitution approach is also clear enough, though it has long been regarded as incompetently implemented (Diaz-Alejandro, 1970; Dornbusch and de Pablo, 1990). Most of the others have followed policy paths which, owing to circumstance, incompetence or corruption, lack coherence. The most distinctive characteristic of the policies of nations like Ethiopia, for example, is not that they 
discourage exports but that they seem to discourage all economic activity. The environmental challenges to economies like those of Bangladesh and Sudan or the instability found for much of this period in Nicaragua or the Dominican Republic surely circumscribe the available policy options and limit the effectiveness of their implementation.

In short, it does not appear prudent to accept the performances of these nations as a definitive test of the relative merits of development strategies which emphasize domestically-generated or export-led growth. The test is not a fair one. While the three "tigers" have been justly regarded as development models to be emulated by the outward-inclined, the same cannot be said for those in the most inward category. Simply put, the systematic difference in policy competence of the nations which occupy each of these categories unfairly prejudices the choice between outward- and inward-oriented development.

This is made more clear in connection with a third observation concerning this coding scheme: the criteria include only a partial accounting of the key elements that make up development policy. In fact, this schema is not a direct measure of trade orientation: its focus upon relative prices requires an inference to establish both the intent and, especially, the effect of these policies. This schema does not measure the actual propensity of a nation to maintain or expand a foreign trade sector. This is illustrated by some rather odd codings: Zambia, for example, is regarded as strongly inward-oriented yet in 1963 exports constitute nearly $55 \%$ of their GDP and after 22 years of continuous adherence to these policies exports remain at more than $37 \%$ of GDP. (The average for all 41 nations is about 20\%.) Furthermore, even this decline is probably less a consequence of "inward-oriented" policies than of a massive deterioration in terms of trade associated with unfavorable price movements for the mineral products which dominate Zambia's export bundle. Sri Lanka is similarly coded as strongly inward oriented despite exports which constitute $38 \%$ of GDP in 1963. Furthermore, the previous analysis shows that these are far from isolated cases. It is also apparent that this schema does not tap the full range of behavior that constitutes a true "outward orientation", such as the targeting of investment or infrastructural funds or the pursuit of foreign support from private or public actors.

It has been noted, properly, that measures of policy (like the package which constitutes an outward orientation) and measures of outcomes partially determined by those policies (like actual trade volumes) 
are different things. Still, there should be more than a passing relationship between them. If there is not -and, as we have seen, there is a surprising independence between these two features of national political economies -- one must be concerned about the validity of the policy-based measure. This gap between policy-based and outcome-based measures of development orientation may also contain the key to the apparent conflict between proponents and opponents of development strategies that emphasize trade.

\section{$\underline{\text { Conclusion }}$}

As we have noted above, there is little reason to believe that the notion of "trade orientation" as measured in the World Bank study tells us anything about the desirability of development strategies which rely more or less strongly on trade. There is just not a strong enough relationship between this measure and actual trade levels to sustain such an inference. Instead, it seems probable that the "trade orientation" variable is more an indicator of effective policy making through "getting prices right" than a true schema of trade policy. If so, the appropriate policy advice is not to emphasize an open economy and export growth but to organize development around sound, coherent, policy regardless of the relative balance between the foreign sector and the remainder of the economy. This is especially so because the principal mechanism by which "trade orientation" leads to GDP growth does not appear to lie in export growth. Further, concern about the composition of trade and the relative size of the foreign sector cannot be dismissed on the basis of the analyses presented here.

Moreover, these analyses do not imply that inward oriented development cannot succeed, but only that success is not likely to be found among countries which have taken extreme positions on either end of this dimension. After all, the successful "tigers" are distinguished not by policies which strongly bias production in favor of exports, but by policies that are generally neutral with respect to relative prices. That is, they occupy the rough center of this spectrum. A more appropriate paired comparison is made impossible by the huge imbalance between the dearth of truly outward-oriented nations and the profusion of seemingly inward-oriented ones. 
This imbalance itself should alert us to the likelihood that we are not comparing strategies which are equally grounded in theoretical conviction. Indeed, though it is beyond the confines of this paper to elaborate, a strong case can be made that many of the attributes associated with "inward-oriented policy" are more a consequence of economic failure than a cause of it. This is certainly true of a massively overvalued exchange rate, for example, which is seldom defended as a deliberate or theoretically-coherent economic strategy; rather, it usually results from irresistible forces like differential inflation, price pressure on imported wage goods, uncompetitive producers or other manifestations of macro-economic crisis. The rarity of market forces and political pressures pushing nations to the other extreme is perhaps best indicated by the fact that we have no name comparable to "protectionist" to label the package of policies which would presumably result - greatly undervalued exchange rate, higher taxes on import substitutes than imports, etc.

This then implies that a fairer test of the merits of relatively inward and relatively outward development orientations would attempt to remove this dimension of incompetence or desperation. It is not at all clear how this can be done, but a first step might consist of focusing on the differences between the moderately inward and moderately outward nations. For reasons noted above, there are serious limitations involved in drawing broad generalizations from the experience of three successful nations. At the same time, it may be more appropriate to dismiss most of the cases in the most inward category as irrelevant to the issue at hand, namely ascertaining the relative merits of these two approaches if done right. The contrast between these two middle groups is not stark.

This analysis cannot settle the debate about the relative merits of alternative development strategies, not least because we still cannot effectively measure them. Despite the extraordinarily high profile of the conclusions trumpeted by the initial World Bank study, the less publicized technical follow-ups (Pritchett, 1991:29) contain a more relevant message: "... alternative objective summary measures of policy outward orientation produce entirely different country rankings." It follows that neither trade policy debates nor theoretical clashes about the dangers of trade reliance can be settled by studies which use them. 


\section{$\underline{\text { Endnotes }}$}

1. Greenaway and Nam use per capita real GNP data and weight the group averages by each country's share in the group total. The replication uses real per capita GDP growth rates computed via World Bank regression methods from the well-known Mark 4 data base of the International Comparison Project (Summers and Heston, 1988), but the nations are not weighted in computing group means.

2. These results generally compare with those of Alam (1991). Despite a different sample and a different time period, his analysis produced a parameter estimate of $1.94\left(\mathrm{t}=5.7\right.$ and $\left.\mathrm{R}^{2}=.45\right)$ for $1965-73$ and a value of $1.64\left(\mathrm{t}=5.1\right.$ and $\left.\mathrm{R}^{2}=.42\right)$ for $1973-84$.

3. The measure consists of life expectancy and infant mortality, scaled and combined via the Morris (1979) method. Details can be found in Moon and Dixon (1992). The original data are from the World Tables data set made available in machine readable form through the ICPSR (1989).

4. The standard measure of foreign sector size is the value of imports and/or exports as a percentage of GDP. The text tables report the primary analyses, which use exports for simplicity and to maintain comparability with most other studies. Except where noted, this decision is inconsequential simply because imports and exports are so highly correlated. In this sample, "exports as a percentage of GDP" and "imports as a percentage of GDP" are correlated at .98, .96, and .91 in 1963, 1973, and 1985, respectively. This is not surprising, of course, because imports are largely constrained by export revenues, especially over the longer term.

5. A variety of models combining transformations of GDP and population fit about equally well. For this analysis, both logged GDP and logged population as well as their squares are regressed on logged trade intensity. The $\mathrm{R}^{2}$ of these estimations were .45 in 1963 and .52 in both 1973 and 1985.

6. The pattern is very similar whether exports or imports are used. The analyses which substitute imports but otherwise parallel Tables 3, 5, and 6 are available from the author.

7. The commodity concentration variable is an average of the values for 1960, 1965, and 1970 derived from Taylor and Jodice (1982). The data on primary products comes from the World Bank's World Tables (ICPSR, 1987), but it does not begin until 1965. The change measure presented is the compounded average annual change, but neither an alternative technique for computing the measure (e.g. simple change) nor an elaborated model (e.g. including initial levels as a predictor) altered the conclusion.

8. Export growth is computed as an annual percentage increase in exports as a percentage of GDP. Such a composition removes the definitional relationship between export growth and GDP growth. Normalizing the export percentage through the residual technique discussed earlier produced no appreciable difference in the results. All analyses using export (or import) growth suffer the loss of one case to missing data in the 1973-85 period. Including the initial level of exports as a percentage of GDP in addition to the growth measure also does not change the basic results. The reported estimates are OLS. Singapore barely exceeded the critical value of DFFITS and no other nation approached it. Moreover, the BIE estimates were nearly identical to those of OLS.

9. Because the "strongly inward oriented" category is the base-line from which the deviations of other categories are computed, the number in parentheses is the $t$ value associated with the difference of means between each category and the strongly inward oriented grouping. For example, the average export level in 1963 for nations strongly inward oriented during 1963-73 is .18 while the average for the strongly outward 
oriented nations is .77 . The displayed t value of 4.6 indicates that this contrast is statistically significant.

10. The measure is the average annual change in trade as a percentage of GNP; a similar pattern was found with the simple difference between relative openness at the beginning and end of the period.

11. The data is from ICPSR (1987). For all nations in the sample the average value of official foreign aid in 1985 is $4.6 \%$ of GDP. For the strongly inward, the value is $7.2 \%$, declining to $4.2 \%$ for the moderately inward, $1.9 \%$ for the moderately outward, and under .1\% for the strongly outward. The debt analysis was performed using the external public debt outstanding in both 1970 and 1985 as a percentage of GDP (ICPSR, 1987). The variance across nations both within and between categories is too large to detect any relationship. 


\section{Bibliography}

Alam, M. Shahid (1991) "Trade Orientation and Macroeconomic Performance in LDC's: An Empirical Study," Economic Development and Cultural Change 39,4: 839-848.

Balassa, Bela (1985) "Exports, Policy Choices, and Economic Growth in Developing Countries after the 1973 Oil Shock," Journal of Development Economics 18:23-35.

Barro, Robert J. (1991) "Economic Growth in a Cross-section of Countries,"Quarterly Journal of Economics May: $407-443$.

Bhagwati, Jagdish N. (1978) Foreign Trade Regimes and Economic Development: Anatomy and Consequences of Exchange Control Regimes

(Cambridge, Mass.: Ballinger Pub. Co).

Bhagwati, Jagdish (1986) "Rethinking Trade Strategy" in John Lewis and Valeriana Kallab,eds. Development Strategies Reconsidered New Brunswick: Transaction Books.

Bhagwati, Jagdish, and T. N. Srinivasan (1979) "Trade Policy and Development" in Rudiger Dornbusch and Jacob Frenkel, ed. International Economic Policy: Theory and Evidence Baltimore: Johns Hopkins University Press, pp. 1-35.

Choi, Kwang (1983) Theories of Comparative Economic Growth Ames: Iowa State University Press.

Cline, William R. (1982) "Can the East Asian Model of Development Be Generalized?" World Development 10,2:81-90.

Corden, W.M. (1971) "The Effects of Trade on the Rate of Growth" in Trade, Balance of Payments, and Growth Amsterdam: North-Holland.

Crafts, N.F.R. (1973) "Trade as a Handmaiden of Growth: An Alternative View" Economic Journal 875-884.

Dean, Judith M., Seema Desai, and James Reidel (1994) "Trade Policy Reform in Developing Countries since 1985: A Review of the Evidence," World Bank Discussion Paper 267.

Delacroix, Jacques (1977) "The Export of Raw Materials and Economic Growth: A Cross-National Study," American Sociological Review 42: 795-808.

Diaz-Alejandro, Carlos (1970) Essays on the History of the Argentine Republic New Haven: Yale University Press.

Dollar, David (1992) "Outward-oriented Developing Economies Really Do Grow More Rapidly: Evidence from 95 LDCs, 1976-1985," Economic Development and Cultural Change 40, 3: 523-44.

Dornbusch, Rudiger and Juan Carlos de Pablo (1990) "Debt and Macroeconomic Instability in Argentina," in Jeffrey Sachs, ed. Developing Country Debt and Economic Performance volume 2. Chicago: University of Chicago Press.

Emmanuel, Arghiri (1972) UnequalExchange: A Study of the Imperialism of Free Trade New York: Monthly Review Press.

Frank, Andre Gunder (1966) "The Development of Underdevelopment," Monthly Review 18(September): 17-31.

Galtung, Johan (1971) "A Structural Theory of Imperialism" Journal of Peace Research 13,2:81-117.

Greenaway, David (1986) "Characteristics of Industrialization and Economic Performance Under Alternative Development Strategies" 
Greenaway, David and Chong Hyun Nam (1988) "Industrialisation and Macroeconomic Performance in Developing Countries under Alternative Trade Strategies" Kyklos 41,3: 419-435.

Griffin, Keith (1989) Alternative Strategies for Economic Development London: Macmillan.

Harrison, Ann (1991) "Openness and Growth: A Time Series, Cross-Country Analysis for Developing Countries," World Bank Policy Research Working Paper Series \#809.

Heitger, Bernhard (1986) "Import Protection and Export Performance - Their Impact on Economic Growth" Weltwirtschaftliches Archiv 260: 249-260.

Hilton, Gordon (1976) Intermediate Politometrics New York: Columbia University Press.

Hirschman, Albert (1958) The Strategy of Economic Development (New Haven: Yale University Press).

Hsiao, M.W. (1987) "Tests of Causality and Exogeneity between Exports and Economic Growth: The Case of the Asian NIC'S" Journal of Economic Development 12, 2: 143-159.

Inter-university Consortium for Political and Social Research (1989) World Tables of Economic and Social Indicators, 1950-1987.

Jung, W. and P. Marshall (1985) "Exports, Growth, and Causality in Developing Countries," Journal of Development Economics 14: 241-250.

Kravis, Irving (1970) "Trade as a Handmaiden of Growth: Similarities Between the Nineteenth and Twentieth Centuries", The Economic Journal 80: 850-872.

Krueger, Anne (1978) Foreign Trade Regimes and Economic Development: Liberalization Attempts and Consequences Cambridge, Mass. : Ballinger Pub. Co.

Leamer, Edward (1988) "Measures of Openness" in Robert Baldwin, ed. Trade Policy Issues and Empirical Analysis Chicago: University of Chicago Press.

Levine, Ross and David Renelt (1992) "A Sensitivity Analysis of Cross-Country Growth Regressions," American Economic Review 82: 942-963.

Lewis, W. Arthur (1978) The Evolution of the International Economic Order Princeton University Press.

MacBean, Alisdair (1966) Export Instability and Economic Development (London: George Allen and Unwin).

Mahler, Vincent (1980) Dependency Approaches to International Political Economy: A Cross-National Study New York: Columbia University Press.

Michaely, Michael (1977) "Exports and Growth: An Empirical Investigation" Journal of Development Economics 4:49-53.

Milner, Chris (1988) "Trade Strategies and Economic Development: Theory and Evidence" in David Greenaway, ed. Economic Development and International Trade New York: St. Martin's Press, pp. 55-76.

Moon, Bruce E. (1991) The Political Economy of Basic Human Needs Ithaca: Cornell University Press.

Moon, Bruce E. and William J.Dixon (1992) "Basic Needs and Growth-Welfare Trade-offs," International Studies Quarterly 36: 191-212. 
Morris, Morris David (1979) Measuring the Condition of the World's Poor: The Physical Quality of Life Index New York: Pergamon.

Myrdal, Gunnar (1957) Economic Theory and Under-Developed Regions London.

Nurkse, Ragnar (1961) Equilibrium and Growth in the World Economy Harvard University Press.

Pack, Howard (1988) "Industrialization and Trade" in Hollis Chenery and T.N. Srinivasan, eds. Economics volume 1 Amsterdam: North Holland, pp.333-380.

Prebisch, Raul (1962) "The Economic Development of Latin America and Its Principal Problems," Economic Bulletin for Latin America 7 (February): 1-22.

Pritchett, Lance (1991) "Measuring Outward Orientation in Developing Countries: Can it be done?," World Bank Policy Research Working Paper Series \#566.

Ram, Rati (1985) "Exports and Economic Growth: Some Additional Evidence" Economic Development and Cultural Change 33, 2: 415-425.

Riedel, James (1988) "Trade as an Engine of Growth: Theory and Evidence" in David Greenaway, ed. Economic Development and International Trade New York: St. Martin's Press, pp. 25-54.

Robertson, Dennis (1938) "The Future of International Trade," Economic Journal 48: 1-14.

Robinson, Joan (1979) Aspects of Development and Underdevelopment Cambridge University Press.

Rubinson, Richard (1977) "Dependence, Government Revenue, and Economic Growth, 1955-1970," Studies in Comparative International Development 12: 3-28.

Salvatore, Dominick and Thomas Hatcher (1992) "Inward Oriented and Outward Oriented Trade Strategies, "The Journal of Development Studies 27, 3: 7-25.

Senghaas, Dieter (1985) The European Experience: A Historical Critique of Development Theory Leamington Spa: Berg.

Simon, H.A. (1957) Models of Man New York: Wiley.

Singer, Hans W. (1950) "The Distribution of Trade Between Investing and Borrowing Countries," American Economic Review 40: 473-485.

Smith, David (1975) "Public Consumption and Economic Performance", National Westminster Bank Quarterly review November: 17-30.

Summers, Robert and Alan Heston (1988) "A New Set of International Comparisons of Real Product and Price Levels: Estimates for 130 Countries, 1950-1985," Review of Income and Wealth 34,1: 1-25.

Syrquin, Moshe and Hollis Chenery (1989) "Three Decades of Industrialization" World Bank Economic Review3,2: 145181.

Taylor, Charles and David Jodice (1982) World Handbook of Political and Social Indicators III: 1948-1982 Ann Arbor, Michigan: Inter-university Consortium for Political and Social Research.

Thomas, Vinod, John Nash and Associates (1991) Best Practices in Trade Policy Reform Oxford University Press. 
World Bank (1983) World Development Report 1983 Oxford University Press.

World Bank (1987) World Development Report 1987 Oxford University Press. 
Table 1

Average Annual GDP Per Capita Growth broken down by Policy Orientation

\begin{tabular}{lccccc}
\multicolumn{1}{c}{$(\mathrm{N}=41)$} & \multicolumn{2}{c}{$\begin{array}{c}\text { Reported by } \\
\text { Greenaway } \\
\text { and Nam }\end{array}$} & \multicolumn{2}{c}{ Replication } \\
Strongly outward & $\frac{1963-73}{6.9}$ & $\frac{1973-85}{5.9}$ & & $\frac{1963-73}{7.9}$ & $\frac{1973-85}{6.7}$ \\
Moderately outward & 4.9 & 1.7 & 4.2 & 2.2 \\
Moderately inward & 3.9 & 1.8 & & 2.5 & 1.2 \\
Strongly inward & 1.6 & -.1 & 1.3 & -.7
\end{tabular}




\section{Table 2 \\ Effects of Trade Orientation on GDP growth}

\begin{tabular}{|c|c|c|c|c|}
\hline & $1 \quad 1$ & & L & 2 \\
\hline Trade orientation & 1.57 & $(6.9)$ & & \\
\hline Strongly outward & & & 5.50 & $(6.0)$ \\
\hline Moderately outward & & & 2.77 & $(5.2)$ \\
\hline Moderately inward & & & 1.47 & $(2.8)$ \\
\hline Basic needs, 1963 & .04 & $(2.4)$ & .03 & $(1.8)$ \\
\hline Investment/GDP, 1963 & .08 & $(2.2)$ & .07 & $(2.0)$ \\
\hline Logged Real GDP, 1963 & -.78 & $(-1.7)$ & -.64 & $(-1 \cdot 3)$ \\
\hline Constant & 2.37 & $(.9)$ & 3.35 & $(1.2)$ \\
\hline adjusted $R^{2}$ & .69 & & .69 & \\
\hline
\end{tabular}

Real GDP per capita growth, 1973-85

$\begin{array}{lrrrr}\begin{array}{l}\text { Trade orientation } \\ \text { Strongly outward }\end{array} & 2.26 & (5.0) & & \\ \text { Moderately outward } & & & 7.89 & (5.1) \\ \text { Moderately inward } & & & 3.69 & (3.5) \\ & & & 1.98 & (2.5) \\ \text { Basic needs, 1973 } & .05 & (1.8) & .05 & (1.6) \\ \text { Investment/GDP, 1973 } & .01 & (.1) & -.00 & (-.1) \\ \text { Logged Real GDP, 1973 } & -2.13 & (-2.8) & -1.90 & (-2.5) \\ \quad \text { Constant } & 8.92 & (2.1) & 10.17 & (2.4) \\ & & & & \\ \text { adjusted R } R^{2} \quad(N=40) & .51 & & .51 & \\ \text { (t values in parentheses) }\end{array}$


Table 3

Effects of Trade Orientation and Exports on GDP growth ( $t$ values in parentheses)

Real GDP per capita growth, 1963-73

Strongly outward

Moderately outward

Moderately inward

Exports/GDP, 1963

Logged Real GDP, 1963

Basic needs, 1963

Investment/GDP, 1963

Constant
11

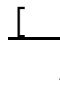

$\frac{3}{5.61(5.9)}$

$2.75(6.2) \quad 2.82(6.4)$

$1.45(3.2) \quad 1.54(3.4)$

$1.64(1.0)$

$-.55(-.9)$

$.05(2.5)$

$.07(1.2)$

$3.05(.9)$

.34

.73

.71

Real GDP per capita growth, 1973-85

Strongly outward

Moderately outward

Moderately inward

Exports/GDP, 1973

Logged Real GDP, 1973

Basic needs, 1973

Investment/GDP, 1973

Constant

adjusted $R^{2} \quad(N=40)$

$\begin{array}{rrrrrrr} & & 7.75 & (5.3) & 12.83 & (4.9) \\ & & 3.42 & (4.0) & 3.57 & (4.5) \\ 2.03 & (.0) & 1.65 & (2.5) & 2.26 & (3.5) \\ -2.01 & (-2.5) & -2.11 & (-3.3) & -2.28 & (-3.9) \\ .10 & (3.2) & .06 & (2.3) & .06 & (2.4) \\ .02 & (3.3) & -.00 & (-.1) & .02 & (-5) \\ 9.68 & (2.2) & 11.49 & (3.2) & 13.44 & (4.0)\end{array}$

.21

.56

.57 


\section{Table 4}

\section{Effects of Trade Orientation and Dependence on Growth}

Real GDP per capita growth, 1963-73

\begin{tabular}{|c|c|c|c|c|c|c|}
\hline Logged real GDP, 1963 & 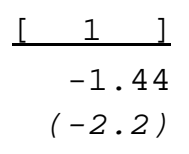 & $\begin{array}{l}2 \\
-.53 \\
(-.8)\end{array}$ & $\frac{3}{-1.03}$ & $\frac{4}{-.92}$ & $\frac{5}{-.65}$ & $\begin{array}{r}6 \\
-.71 \\
(-1.5)\end{array}$ \\
\hline Basic needs, 1963 & $\begin{array}{l}.06 \\
(3.1)\end{array}$ & $\begin{array}{r}.05 \\
(2.2)\end{array}$ & $\begin{array}{r}.07 \\
(3.5)\end{array}$ & $\begin{array}{r}.02 \\
(1.6)\end{array}$ & $\begin{array}{r}.03 \\
(1.7)\end{array}$ & $\begin{array}{r}.03 \\
(2.0)\end{array}$ \\
\hline Investment/GDP, 1963 & $\begin{array}{l}.09 \\
(1.7)\end{array}$ & $\begin{array}{r}.02 \\
(.5)\end{array}$ & $\begin{array}{l}.06 \\
(1.3)\end{array}$ & $\begin{array}{r}.09 \\
(2.7)\end{array}$ & $\begin{array}{l}.06 \\
(1.8)\end{array}$ & $\begin{array}{r}.07 \\
(2.1)\end{array}$ \\
\hline Strongly outward & & & & $\begin{array}{r}4.88 \\
(5.7)\end{array}$ & $\begin{array}{l}5.15 \\
(4.3)\end{array}$ & $\begin{array}{r}4.54 \\
(4.8)\end{array}$ \\
\hline Moderately outward & & & & $\begin{array}{r}2.60 \\
(5.4)\end{array}$ & $\begin{array}{r}2.59 \\
(4.7)\end{array}$ & $\begin{array}{l}2.56 \\
(5.2)\end{array}$ \\
\hline Moderately inward & & & & $\begin{array}{r}.90 \\
(1.7)\end{array}$ & $\begin{array}{r}1.28 \\
(2.4)\end{array}$ & $\begin{array}{r}1.00 \\
(1.9)\end{array}$ \\
\hline Commodity concentration & $\begin{array}{l}-4.63 \\
(-2.5)\end{array}$ & & & $\begin{array}{l}-3.29 \\
(-2.5)\end{array}$ & & \\
\hline Primary products, 1965 & & $\begin{array}{l}-4.70 \\
(-3.2)\end{array}$ & & & $\begin{array}{l}-.48 \\
(-.3)\end{array}$ & \\
\hline $\begin{array}{l}\text { Primary products } \\
\text { growth, 1965-73 }\end{array}$ & & & $\begin{array}{r}-.27 \\
(-3.1)\end{array}$ & & & $\begin{array}{l}-.15 \\
(-2.1)\end{array}$ \\
\hline Constant & $\begin{array}{c}10.33 \\
(2.5)\end{array}$ & $\begin{array}{r}8.15 \\
(2.2)\end{array}$ & $\begin{array}{l}5.71 \\
(1.6)\end{array}$ & $\begin{array}{r}6.58 \\
(2.4)\end{array}$ & $\begin{array}{r}4.18 \\
(1.4)\end{array}$ & $\begin{array}{r}3.75 \\
(1.4)\end{array}$ \\
\hline Adjusted $R^{2}$ & .38 & .44 & .43 & .73 & .68 & .72 \\
\hline
\end{tabular}

Real GDP per capita growth, 1973-85

\begin{tabular}{|c|c|c|c|c|c|c|}
\hline Logged real GDP, 1973 & $\begin{array}{l}-2.19 \\
(-2.3)\end{array}$ & $\begin{array}{l}-1.87 \\
(-2.2)\end{array}$ & $\begin{array}{l}-1.94 \\
(-2.1)\end{array}$ & $\begin{array}{l}-2.13 \\
(-2.7)\end{array}$ & $\begin{array}{l}-2.00 \\
(-2.7)\end{array}$ & $\begin{array}{l}-1.99 \\
(-2.8)\end{array}$ \\
\hline Basic needs, 1973 & $\begin{array}{r}.11 \\
(3.2)\end{array}$ & $\begin{array}{l}.10 \\
(3.1)\end{array}$ & $\begin{array}{r}.12 \\
(3.5)\end{array}$ & $\begin{array}{r}.05 \\
(1.7)\end{array}$ & $\begin{array}{r}.05 \\
(1.8)\end{array}$ & $\begin{array}{r}.06 \\
(2.0)\end{array}$ \\
\hline Investment/GDP, 1973 & $\begin{array}{l}.04 \\
(.8)\end{array}$ & $\begin{array}{l}.00 \\
(.1)\end{array}$ & $\begin{array}{l}.01 \\
(.2)\end{array}$ & $\begin{array}{l}.02 \\
(.1)\end{array}$ & $\begin{array}{l}.00 \\
(.2)\end{array}$ & $\begin{array}{l}.01 \\
(.1)\end{array}$ \\
\hline Strongly outward & & & & $\begin{array}{r}7.39 \\
(4.8)\end{array}$ & $\begin{array}{r}6.55 \\
(3.7)\end{array}$ & $\begin{array}{r}7.31 \\
(5.0)\end{array}$ \\
\hline Moderately outward & & & & $\begin{array}{r}3.62 \\
(3.5)\end{array}$ & $\begin{array}{r}3.58 \\
(3.4)\end{array}$ & $\begin{array}{l}3.36 \\
(3.3)\end{array}$ \\
\hline Moderately inward & & & & $\begin{array}{r}2.10 \\
(2.7)\end{array}$ & $\begin{array}{r}2.03 \\
(2.6)\end{array}$ & $\begin{array}{r}2.03 \\
(2.7)\end{array}$ \\
\hline Commodity concentration & $\begin{array}{l}-4.93 \\
(-2.0)\end{array}$ & & & $\begin{array}{l}-2.53 \\
(-1.2)\end{array}$ & & \\
\hline Primary products, 1973 & & $\begin{array}{l}-4.70 \\
(-3.1)\end{array}$ & & & $\begin{array}{l}-2.13 \\
(-1.4)\end{array}$ & \\
\hline $\begin{array}{l}\text { Primary products } \\
\text { growth, 1973-85 }\end{array}$ & & & $\begin{array}{r}-.27 \\
(-2.5)\end{array}$ & & & $\begin{array}{r}-.18 \\
(-2.1)\end{array}$ \\
\hline Constant & $\begin{array}{l}11.88 \\
(2.1)\end{array}$ & $\begin{array}{r}12.45 \\
(2.4)\end{array}$ & $\begin{array}{r}7.85 \\
(1.6)\end{array}$ & $\begin{array}{c}11.94 \\
(2.6)\end{array}$ & $\begin{array}{l}11.99 \\
(2.7)\end{array}$ & $\begin{array}{r}9.74 \\
(2.4)\end{array}$ \\
\hline Adjusted $R^{2}$ & .26 & .36 & .30 & .54 & .55 & .58 \\
\hline
\end{tabular}


(t values in parentheses)

Table 5

Effects of Trade Orientation and Export Growth on GDP growth

\begin{tabular}{|c|c|c|c|c|c|c|}
\hline & $\perp$ & 11 & 2 & $1 \perp$ & 3 & 1 \\
\hline Strongly outward & & & 5.50 & $(6.0)$ & 4.84 & $(4.9)$ \\
\hline Moderately outward & & & 2.77 & $(5.2)$ & 2.58 & $(4.8)$ \\
\hline Moderately inward & & & 1.47 & $(2.8)$ & 1.32 & $(2.5)$ \\
\hline Export growth, 1963-73 & .24 & $(3.1)$ & & & .10 & $(1.6)$ \\
\hline Logged Real GDP, 1963 & -.76 & $(-1.2)$ & -.64 & $(-1 \cdot 3)$ & -.62 & $(-1 \cdot 2)$ \\
\hline Basic needs, 1963 & .07 & $(3.3)$ & .03 & $(1.8)$ & .03 & $(1.9)$ \\
\hline Investment/GDP, 1963 & .07 & $(1.4)$ & .07 & $(2.0)$ & .08 & $(2.2)$ \\
\hline $\begin{array}{c}\text { Constant } \\
\text { Contingt } R^{2}\end{array}$ & $\begin{array}{c}4.00 \\
43\end{array}$ & $(1.1)$ & $\begin{array}{c}3.35 \\
69\end{array}$ & $(1.2)$ & $\begin{array}{c}3.04 \\
70\end{array}$ & $(1.1)$ \\
\hline
\end{tabular}

Real GDP per capita growth, 1973-85

Strongly outward

Moderately outward

Moderately inward

Export growth, 1973-85 .34 (2.9)
$7.09(4.2) 6.77(4.3)$

$3.73(3.5) \quad 2.78(2.7)$

$1.95(2.5) \quad 1.79(2.5)$

$.28(2.7)$

Logged Real GDP, $1973-2.35(-2.7)-1.90 \quad(-2.5)-2.37(-3.3)$

Basic needs, $1973 \quad .09(3.0) \quad .05(1.6) \quad .05(1.7)$

Investment/GDP, $1973-.02(-.4)-.02(-.4)-.01(-.2)$

Constant $\quad 13.01(2.6) 10.34(2.4) 13.73(3.4)$

adjusted $R^{2}\left(\begin{array}{llll}N=39 & .29 & .43\end{array}\right.$

(t values in parentheses) 
Table 6

Trade levels broken down by policy orientation

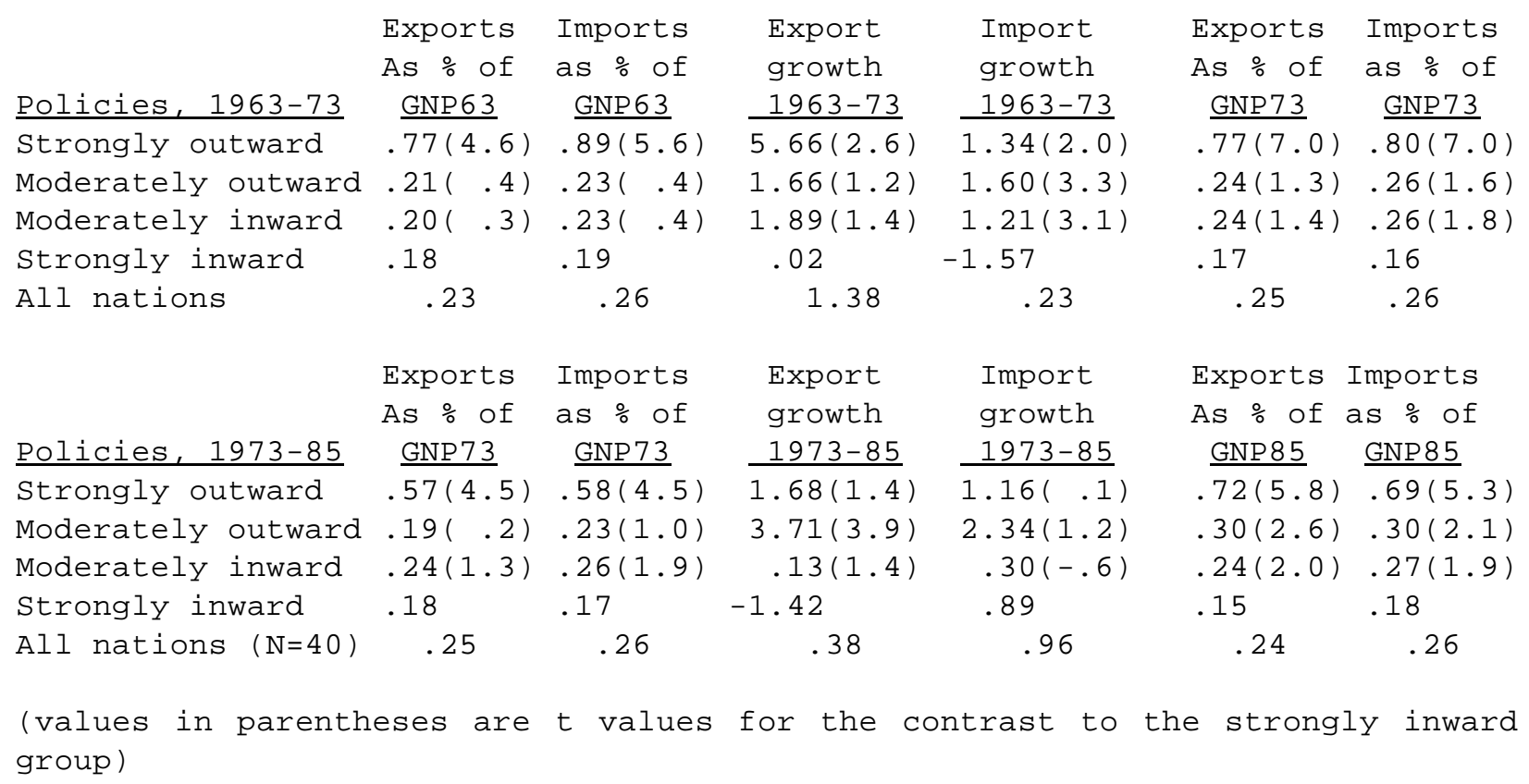




\section{Table 7}

\section{Export composition broken down by policy orientation}

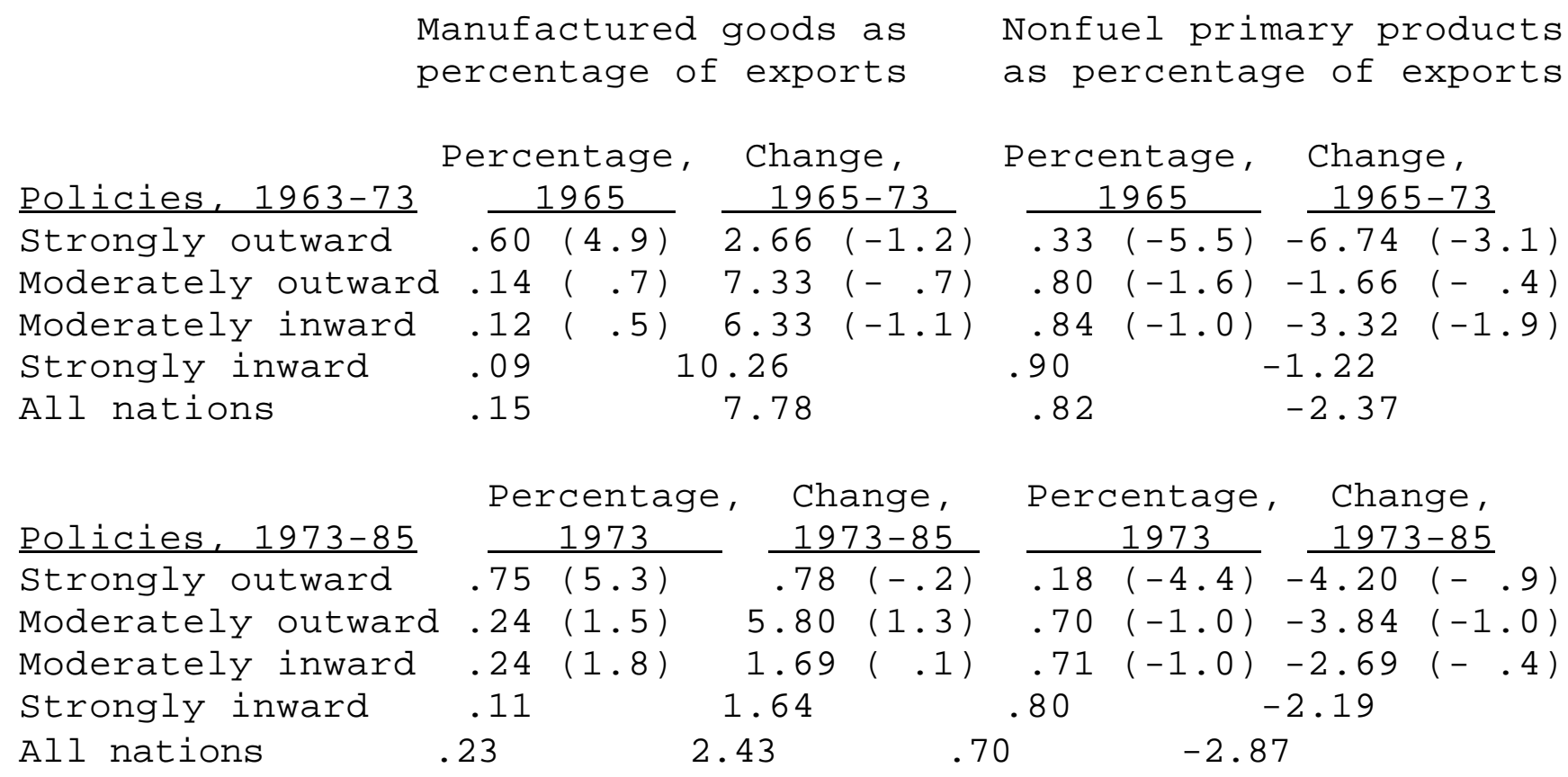




\section{Appendix A}

The usual array of diagnostics used to detect multi-collinearity and heteroscedasticity uncovered no problems, but some observations did manifest extreme values on some variables. Ordinary least squares (OLS) estimates can inflate the influence of such cases so that parameter estimates reflect a few outlying observations more than the sample as a whole. Three standard diagnostics were employed to detect disproportionate influence: the studentized residuals, the $h_{i}$ (leverage) and DFFITS (which combines the previous two). While no established standard exists for determining a critical value on these diagnostics, Velleman and Welsch (1981) suggest that a |DFFITS| greater than 2 represents a potential problem in a sample of this size. Because of Singapore's extreme value on the measure of export sector size, the analyses reported in Tables 3 and 4 frequently identified it as an influential case, sometimes with a DFFITS above the critical value of 2 . For similar reasons, other nations had relatively large values on the component diagnostics as well, though none approached the |DFFITS| value of 2.

Three alternatives present themselves to minimize the leverage of these cases on both the overall fit of the model and the relative sizes of the individual coefficients. First, the variable in question might be transformed to reduce its skewness. When export percentage is logged, the skewness is reduced but the influence of Singapore remains uncomfortably large. Second, the variable might be replaced with a less skewed proxy, such as the residual "openness" measure discussed in the text. This variable is somewhat less skewed than the original, but the leverage diagnostics are similar. Third, the offending case(s) might be removed.

Neither the estimate with all cases included nor the estimate with influential cases removed is fully satisfactory. For example, in the analysis reported in the first column of Table 3, the apparent effect of export sector size on growth is $2.23(\mathrm{t}=1.7)$ with Singapore included but $-.37(\mathrm{t}=-.2)$ without it. The adjusted $\mathrm{R}^{2}$ falls from .33 to .20 . It is difficult to feel confident that exports lead to growth, despite an 
estimate approaching .05 level significance, when there is virtually no relationship (indeed, it is slightly negative) in the remainder of the sample. However, it is uncomfortable to simply remove the aberrant case because of its theoretical centrality: it is one of only three strongly outward-oriented nations and it is the most export reliant. (The second largest |DFFITS| value belongs to Hong Kong, the second of these three.) Eliminating these cases would deprive the analysis of the information they contain about this relationship.

The alternative pursued here is to replace the original OLS estimation with a bounded influence estimation (BIE). Table 3 follows Welsch (1980) in weighting the cases so that all are included in the analysis but the influence of each is bounded. This weighted least squares (WLS) approach weights each case according to its value on the DFFITS diagnostic. When $\mid$ DFFITS $\mid$ is less than .34 , the weight is 1 ; otherwise the weight is .34/DFFITS|. The resulting estimates, as illustrated by the first column of Table 3, lie somewhere between the extremes which result from either eliminating the influential cases or allowing them to dominate the estimates. While some WLS (BIE) parameters reported in Table 3 are clearly different than those obtained from an OLS estimate, the results do not shift radically enough to alter the theoretical interpretation. Note that even in column one of Table 3, which produced the largest difference between the OLS and the WLS estimates of any of the analyses in this paper, the estimates are not statistically significant under either technique.

In the analyses of Table 2, no case approached a |DFFITS| of 2, but because several had component diagnostics near their respective critical values, a BIE re-estimation was performed. The results were nearly identical with those of the OLS reported in the text. 
Strongly

Period _ Outward-oriented

Moderately

Moderately

Outward-oriented Inward oriented Inward-oriented

1963-73 Hong Kong

Rep. of Korea

Singapore
Brazil

Cameroon

Colombia

Costa Rica

Cote d'Ivoire

Guatemala

Indonesia

Israel

Malaysia

Thailand
Bolivia

El Salvador

Honduras

Kenya

Madagascar

Mexico

Nicaragua

Nigeria

Philippines

Senegal

Tunisia

Yugoslavia
Argentina

Bangladesh

Burundi

Chile

Dominican Rep.

Ethiopia

Ghana

India

Pakistan

Peru

Sri Lanka

Sudan

Tanzania

Turkey

Uruguay

Zambia
Hong Kong

Rep. of Korea

Singapore

\section{Brazil}

Chile

Israel

Malaysia

Thailand

Tunisia

Turkey

Uruguay

\section{Cameroon}

Colombia

Costa Rica

Cote d'Ivorie

El Salvador

Guatemala

Honduras

Indonesia

Kenya

Mexico

Nicaragua

Pakistan

Philippines

Senegal

Sri Lanka

Yugoslavia
Argentina

Bangladesh

Bolivia

Burundi

Dominican Rep.

Ethiopia

Ghana

India

Madagascar

Nigeria

Peru

Sudan

Tanzania

Zambia 